\title{
THE OCCURRENCE OF METHEMOGLOBINEMIA DURING SULFANILAMIDE THERAPY
}

\author{
By CHARLES L. FOX, JR.,1 AND JAMES E. CLINE \\ (From the Department of Bacteriology and Immunology, Harvard Medical School, and the \\ Chemical Laboratory of Harvard University, Cambridge)
}

(Received for publication August 28, 1939)

The presence of methemoglobin, more rarely sulfhemoglobin, in the blood of patients treated with sulfanilamide has been reported by many investigators (1 a-f). Evelyn and Malloy (2), using their photoelectric colorimeter, found both these pigments but felt they were not responsible for the "cyanosis." Wendel (3), using his visual spectroscopic method (4), found methemoglobin and (occasionally) sulfhemoglobin. On the other hand, Marshall (5), Posner (6a) in many instances, Chesley (6b), and some occasional observers have failed to find the characteristic band of methemoglobin.

A little spectroscopic experimentation with pure methemoglobin will speedily convince anyone that the light absorption characteristics of methemoglobin renders visual detection of the band at $630 \mathrm{~m} \mu$ rather difficult in the presence of a large excess of hemoglobin. Even Wendel's ingenious method (4) does not eliminate the difficulty of finding this band. If the personal visual factor might be eliminated, incontrovertible evidence might be obtained.

This is possible with the Hardy recording spectrophotometer (7) which accurately draws a curve showing the light transmission of a sample from 400 to $700 \mathrm{~m} \mu$. Typical curves of the blood of patients receiving sulfanilamide are reproduced (Figure 1) with normal controls. The prominent depression at $630 \mathrm{~m} \mu$ is readily seen. In one case a depression at $620 \mathrm{~m} \mu$ is also seen indicating the presence of sulfhemoglobin.

In these patients from 10 to 18 per cent methemoglobin was estimated to be present by using Beer's and Bouguer's laws and absorption coefficients obtained on pure solutions by the Hardy recording spectrophotometer (Table I).

Inasmuch as sulfanilamide in vitro does not produce methemoglobin, the mechanism of its formation in vivo remains unexplained. Further ex-

\footnotetext{
1 Moritz Rosenthal Fellow, Mount Sinai Hospital, New York City.
}

TABLE I

Absorption coefficients

\begin{tabular}{c|c|c|c|c}
\hline \hline$\lambda \mathrm{m} \mu$ & Hemoglobin & $\begin{array}{c}\text { Methemo- } \\
\text { globin }\end{array}$ & $\begin{array}{c}\text { Colored } \\
\text { residue }\end{array}$ & $\begin{array}{c}\text { Blue } \\
\text { substance }\end{array}$ \\
\hline 700 & 0.0825 & 0.114 & 8.64 & 24.1 \\
660 & 0.0862 & 0.472 & 10.8 & 56.8 \\
630 & 0.133 & 2.32 & 17.6 & 75.0 \\
620 & 0.179 & 2.18 & 19.1 & 80.2 \\
600 & 0.566 & 1.98 & 21.9 & 89.1 \\
580 & 7.14 & 2.40 & 24.2 & 93.9 \\
560 & 5.83 & 2.52 & 25.9 & 92.9 \\
540 & 8.60 & 3.70 & 26.7 & 87.2 \\
520 & 4.12 & 4.75 & 27.1 & 78.1 \\
500 & 3.30 & 5.57 & 27.8 & 68.5 \\
480 & 4.15 & 5.00 & 29.4 & 59.8 \\
460 & 6.82 & 5.69 & 32.1 & 53.6 \\
440 & 16.12 & 11.5 & 36.5 & 49.6 \\
\hline
\end{tabular}

Transmission curves were obtained with solutions of each substance.

These coefficients were calculated after using the equation

$$
\log \frac{100}{\% \text { transmission }}=k c d \text {. }
$$

$k=$ absorption coefficient

$c=$ concentration of the solution-1 gram per $100 \mathrm{cc}$. for hemoglobin and methemoglobin

$d=$ thickness of cell in $\mathrm{cm}$.

periments showed that when the blue derivative (8) (a reversible oxidation-reduction system formed by the aerobic ultra-violet irradiation of dilute aqueous sulfanilamide (9)) is added to hemoglobin, methemoglobin is formed ${ }^{2}$ (Figure 2). Using the accurate Hardy recording spectrophotometer, and applying Beer's and Bouguer's laws, we analyzed the resulting solution. Assuming that hemoglobin and methemoglobin were the only colored components, the transmissions at 12 different wavelengths from 460 to $700 \mathrm{~m} \mu$ were calculated (Table II, Column B). These do not agree with the experimental values (Table II, Column A), and indicate the presence of another colored component. When a third component, the brown solution resulting from the spontaneous

2 "It is interesting to note, however, that the colored derivatives of sulfanilamide described (by Ottenberg and Fox (8)) convert hemoglobin to methemoglobin in vitro." Wendel (3). 


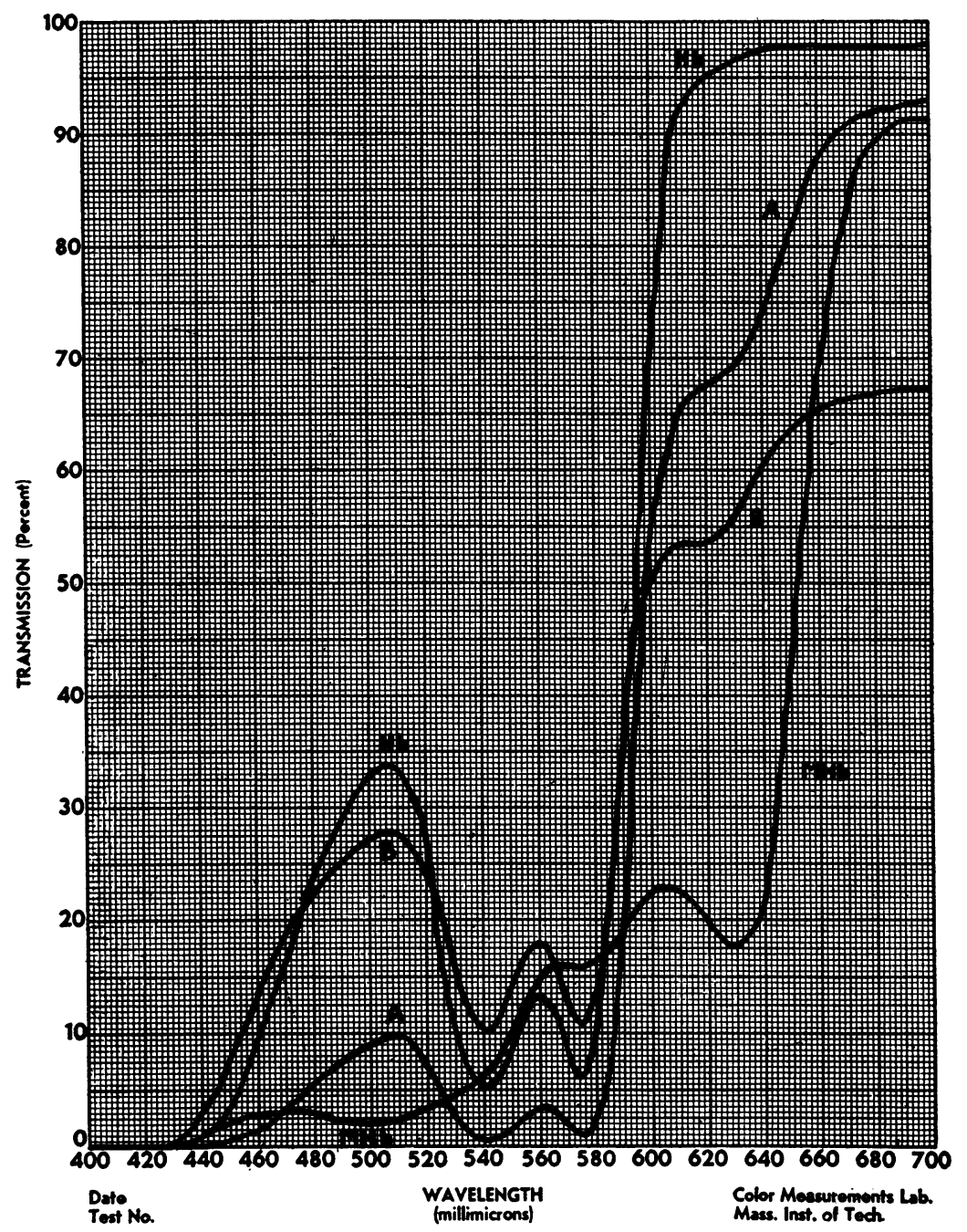

Fig. 1. Curves of Washed, Laked Human Erythrocytes Drawn by Hardy RECORDING SPECTROPHOTOMETER ( $\mathrm{pH}-7.1$ )

$\mathrm{Hb}$ is the curve of $1 / 100$ dilution of blood of normal subject-unaltered hemoglobin solution with characteristic bands at 541 and $573 \mathrm{~m} \mu$.

$\mathrm{MHb}$ is the curve of 100 per cent methemoglobin (same concentration as $\mathrm{Hb}$ ) with prominent band at $630 \mathrm{~m} \mu$.

A is typical curve of patients' blood during sulfanilamide therapy (diluted $1 / 50$ ) showing unmistakable prominence at $630 \mathrm{~m} \mu$ caused by methemoglobin and general depression from 660 to $700 \mathrm{~m} \mu$ (possibly due to a colored oxide of sulfanilamide).

B is curve of patients' blood during sulfanilamide therapy (diluted $1 / 100$ ) showing prominence at $620 \mathrm{~m} \mu$ caused by sulfhemoglobin and general depression from 660 to $700 \mathrm{~m} \mu$ (possibly due to a colored oxide of sulfanilamide).

reduction in air of the blue oxidizing solution, is introduced into the calculations, the predicted transmission values (Table II, Column C) show significantly better agreement with the experimental values (Table II, Column A).
Similar calculations with the data of the curves of patients' blood showed good agreement (Table III) between the observed curve and one predicted on the basis of two components: hemoglobin and methemoglobin in the region from 


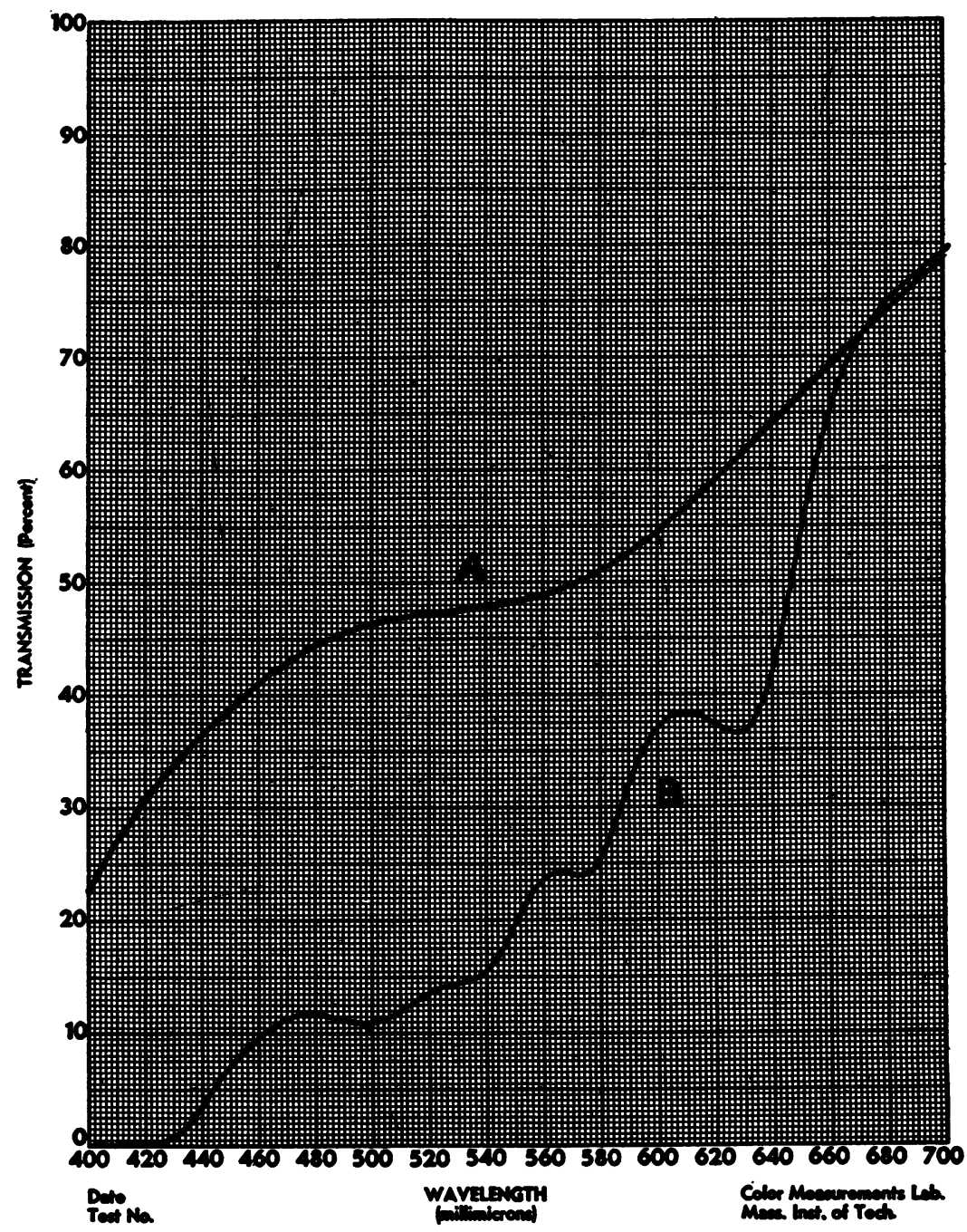

Fig. 2. Formation of Methemoglobin by Photo-oxidation Product of Sulfanilamide

B is curve after reaction between the blue product of irradiation of sulfanilamide and human hemoglobin.

$A$ is curve of brown solution resulting from spontaneous reduction in air of the blue oxidizing solution.

460 to $600 \mathrm{~m} \mu$. In this region, light absorption by hemoglobin is very great, obscuring small deviations. But in the red region beyond, where hemoglobin absorption is minimal, there was demonstrated a small residual absorption. This might be due to any brown substance ${ }^{8}$ such as the brown reduced form of the blue oxidation product (9).

\footnotetext{
8 An unidentified "foreign pigment" is just now reported in normal rats receiving sulfanilamide (10) and Harris and Michel (11) have also observed an extraneous absorption at $670 \mathrm{~m} \mu$.
}

This effect, however, was too slight to influence the gross appearance of blood. These observations suggest that in vivo sulfanilamide is oxidized to the blue derivative which in turn oxidizes hemoglobin to methemoglobin and is itself reversibly reduced. Although this residual absorption indicates in addition to hemoglobin and methemoglobin the existence of a third colored component, and while our spectrophotometric findings are consistent with our interpretation, equally satisfactory fit of the curves might per- 
TABLE II

Hemoglobin-blue substance reaction

\begin{tabular}{c|c|c|c}
\hline \hline$\lambda \mathrm{m} \mu$ & $\begin{array}{c}\text { Experimental } \\
\mathrm{A} \\
\log \frac{1}{T}\end{array}$ & $\begin{array}{c}\text { Calculated } \\
\mathrm{B} \\
\log \frac{1}{T}\end{array}$ & $\begin{array}{c}\text { Calculated } \\
\mathrm{C} \\
\log \frac{1}{T}\end{array}$ \\
\hline 700 & 0.118 & 0.024 & 0.118 \\
660 & 0.211 & 0.094 & 0.182 \\
630 & 0.455 & 0.454 & 0.455 \\
620 & 0.460 & 0.428 & 0.460 \\
600 & 0.478 & 0.396 & 0.478 \\
580 & 0.699 & 0.603 & 0.638 \\
560 & 0.693 & 0.702 & 0.656 \\
540 & 0.886 & 0.885 & 0.827 \\
520 & 0.886 & 1.00 & 0.876 \\
500 & 0.959 & 1.15 & 0.959 \\
480 & 0.943 & 1.05 & 0.931 \\
460 & 1.04 & 1.23 & 1.07 \\
\hline
\end{tabular}

Experimental A-obtained from spectrophotometer curve. Calculated B-on basis of 91.0 per cent methemoglobin and 9.0 per cent hemoglobin.

Calculated $\mathrm{C} \longrightarrow$ on basis of 10.8 per cent hemoglobin, 79.7 per cent methemoglobin and 9.5 per cent colored residue.

Italicized figures are reference points used in computation.

TABLE III

Values of $\log 1 / T$ for sulfanilamide-treated patients

\begin{tabular}{|c|c|c|c|c|c|c|c|c|c|}
\hline \multirow[b]{2}{*}{$\lambda \mathrm{m} \mu$} & \multicolumn{3}{|c|}{ Patient 1} & \multicolumn{3}{|c|}{ Patient 2} & \multicolumn{3}{|c|}{ Patient 3} \\
\hline & $\begin{array}{c}\text { A } \\
\text { experi- } \\
\text { mental }\end{array}$ & $\begin{array}{c}\text { B } \\
\text { cal- } \\
\text { cu- } \\
\text { lated }\end{array}$ & $\begin{array}{c}\text { C } \\
\text { cal- } \\
\text { cu- } \\
\text { lated }\end{array}$ & $\begin{array}{c}\text { D } \\
\text { experi- } \\
\text { mental }\end{array}$ & $\begin{array}{c}\mathrm{E} \\
\text { cal- } \\
\text { cu- } \\
\text { lated }\end{array}$ & $\begin{array}{c}\text { F } \\
\text { cal- } \\
\text { cu- } \\
\text { lated }\end{array}$ & $\begin{array}{c}\text { G } \\
\text { experi- } \\
\text { mental }\end{array}$ & $\begin{array}{c}\text { H } \\
\text { cal- } \\
\text { cu- } \\
\text { lated }\end{array}$ & $\begin{array}{c}\text { I } \\
\text { calcu- } \\
\text { lated }\end{array}$ \\
\hline $\begin{array}{l}700 \\
660 \\
630 \\
620 \\
600 \\
580 \\
560 \\
540 \\
520 \\
500 \\
480 \\
460\end{array}$ & $\begin{array}{l}0.032 \\
0.052 \\
0.159 \\
0.169 \\
0.268 \\
1.68 \\
1.47 \\
2.16 \\
1.16 \\
1.05 \\
1.24 \\
1.80\end{array}$ & $\begin{array}{l}0.025 \\
0.046 \\
0.159 \\
0.161 \\
0.237 \\
1.74 \\
1.45 \\
2.14 \\
1.19 \\
1.05 \\
1.21 \\
1.85\end{array}$ & $\begin{array}{l}0.058 \\
0.052 \\
0.159 \\
0.164 \\
0.245 \\
1.80 \\
1.40 \\
2.17 \\
1.20 \\
1.05 \\
1.21 \\
1.87\end{array}$ & $\begin{array}{l}0.024 \\
0.033 \\
0.090 \\
0.100 \\
0.197 \\
1.64 \\
1.444 \\
2.15 \\
1.08 \\
0.92 \\
1.12 \\
1.70\end{array}$ & $\begin{array}{l}0.021 \\
0.032 \\
0.090 \\
0.098 \\
0.184 \\
1.75 \\
1.440 \\
1.92 \\
1.093 \\
0.92 \\
1.11 \\
1.75\end{array}$ & $\begin{array}{l}0.024 \\
0.033 \\
0.090 \\
0.098 \\
0.185 \\
1.75 \\
1.446 \\
2.12 \\
1.095 \\
0.98 \\
1.11 \\
1.76\end{array}$ & $\begin{array}{l}0.0355 \\
0.056 \\
0.177 \\
0.180 \\
0.260 \\
1.59 \\
1.29 \\
1.93 \\
1.09 \\
0.99 \\
1.14 \\
1.69\end{array}$ & $\begin{array}{l}0.023 \\
0.047 \\
0.17 \gamma \\
0.176 \\
0.236 \\
1.50 \\
1.26 \\
1.86 \\
1.09 \\
0.99 \\
1.11 \\
1.66\end{array}$ & $\begin{array}{l}0.0554 \\
0.059 \\
0.177 \\
0.180 \\
0.250 \\
1.56 \\
1.32 \\
1.92 \\
1.10 \\
0.99 \\
1.13 \\
1.69\end{array}$ \\
\hline
\end{tabular}

Column A-Values of $\log 1 / T$ from experimental curve

Column B-Values calculated on basis of 80.2 per cent hemoglobin and 19.8 per cent methemoglobin

Column C-Values calculated on basis of 82.3 per cent hemoglobin, 17.4 per cent methemoglobin and 0.314 per cent colored residue

Column D-Values from experimental curve

Column E-Values calculated on basis of 90.3 per cent hemoglobin and 9.7 per cent methemoglobin

Column F-Values calculated on basis of 90.6 per cent hemoglobin, 9.3 per cent methemoglobin and $\mathbf{0 . 0 9 6}$ per cent colored residue

Column G-Values of $\log 1 / T$ from experimental curve

Column $\mathrm{H}$-Values calculated on basis of 74.3 per cent hemoglobin and 25.7 per cent methemoglobin

Column I-Values calculated on basis of 78.0 per cent hemoglobin, 21.4 per cent methemoglobin and $\mathbf{0 . 5 7 3}$ per cent colored residue.

Italicized figures are reference points used in computation. haps be obtained on the basis of different assumptions as to the nature of the pigments present. Our interpretation is consistent with the findings but cannot be considered as established by our data.

Further evidence that in vivo sulfanilamide is oxidized is provided by Dr. Sanford Rosenthal (12) who reported indications of hydroxylamine sulphonamide, an oxidation product, in the urine of sulfanilamide-treated animals and patients. Preliminary experiments by one of us (C. L. F.) indicate that the Rosenthal test (13) is positive in the methemoglobin forming colored irradiation products and negative in the unadsorbed colorless residual solution which does not form methemoglobin. The data are correlated with the mode of action of sulfanilamide (14).

\section{SUM MARY}

1. Objective evidence in the form of curves drawn by the Hardy recording spectrophotometer is presented showing the occurrence of methemoglobin and sulfhemoglobin in the blood of sulfanilamide-treated patients.

2. An explanation for the occurrence of methemoglobin in the blood of sulfanilamide-treated patients is provided by the demonstraton in vitro of the conversion of hemoglobin to methemoglobin by certain oxidation products of sulfanilamide.

3. Spectrophotometric evidence for the occurrence in vivo of this reacton is adduced.

We are greatly indebted to Professor George S. Forbes for his valuable suggestions and to Dr. Reuben Ottenberg for helpful criticism. We thank the staff of the Color Measurement Laboratory at the Massachusetts Institute of Technology and the House Staff of the Children's Hospital, Boston, for their cooperation.

\section{BIBLIOGRAPHY}

1. (a) Colebrook, L., and Kenny, M., Treatment of human puerperal infections, and of experimental infections in mice, with prontosil. Lancet, 1936, $1,1279$.

(b) Archer, H. E., and Discombe, G., Sulphaemoglobinaemia; its cause and prevention with special reference to treatment with sulphanilamide. Lancet, 1937, 2, 432.

(c) Paton, J. P. J., and Eaton, J. C., Sulphaemoglobinaemia and methaemoglobinaemia following administration of p-aminobenzenesulphonamide. Lancet, 1937, 1, 1159 and 1369. 
(d) Bensley, E. H., and Ross, J. B., Methaemoglobinaemia due to sulphanilamide therapy. Canad. M. A. J., 1937, 37, 62.

(e) Watson, C. J., Vigness, I., and Spink, W. W., Relation of methemoglobin to the cyanosis observed after sulfanilamide administration. Proc. Soc. Exp. Biol. and Med., 1939, 40, 547.

(f) Campbell, D., and Morgan, T. N., Cyanosis caused by sulphonamide compounds. Lancet, 1939, $2,123$.

2. Evelyn, K. A., and Malloy, H. T., Microdetermination of oxyhemoglobin, methemoglobin and sulfhemoglobin in a single sample of blood. J. Biol. Chem., 1938, 126, 655.

3. Wendel, W. B., The control of methemoglobinemia with methylene blue. J. Clin. Invest., 1939, 18, 179.

4. Wendel, W. B., Methemoglobin determination; clinical method. J. Lab. and Clin. Med., 1938, 24, 96.

5. Marshall, E. K., Jr., and Walzl, E. M., On the cyanosis from sulfanilamide. Bull. Johns Hopkins Hosp., 1937, 61, 140.

6. (a) Posner, I., Guthrie, N. W., and Mattice, M. R., Formation of abnormal blood pigments as complication of sulfanilamide therapy. J. Lab. and Clin. Med., 1938, 23, 804. (b) Chesley, L. C., Cyanosis without sulf- or methemoglobinemia in patients receiving sulfanilamide treatment. J. Clin. Invest., 1938, 17, 445.

7. Hardy, A. C., History of the design of the recording spectrophotometer. J. Opt. Soc. Am., 1938, 28, 360.

8. Ottenberg, R., and Fox, C. L., Jr., Explanation for the cyanosis of sulphanilamide therapy. Proc. Soc. Exp. Biol. and Med., 1938, 38, 479.

9. Fox, C. L., Jr., Cline, J. E., and Ottenberg, R., Products of ultra-violet irradiation of sulfanilamide. J. Pharmacol. and Exper. Therap., 1939, 66, 99.

10. Webb, T. J., and Kniazuk, M., Spectrophotometric examination of blood from animals receiving sulfanilamide. J. Biol. Chem., 1939, 128, 511.

11. Harris, J. S., and Michel, H. O., The formation of methemoglobin and sulfhemoglobin during sulfanilamide therapy. J. Clin. Invest., 1939, 18, 507.

12. Rosenthal, S. M., Experimental chemotherapy with sulfanilamide and related compounds. J. A. M. A., 1939, 113, 1720.

13. Rosenthal, S. M., and Bauer, H., Colorimetric tests for oxidation products of sulfanilamide. Pub. Health Rep., 1939, 54, No. 42.

14. Fox, C. L., Jr., The significance of the oxidation of sulfanilamide during therapy. Am. J. M. Sc. (In press). 